\title{
Dans en Muziek in relatie tot Geneeskunde
}

\author{
J.D. Macfarlane
}

Het is voor velen in de medische wereld al lang bekend dat veel artsen affiniteit met muziek hebben en deze zelfs beoefenen. Zo bestaat er een Nederlands artsenorkest 'I Medici' geheten. Het is ook geen verrassing dat er een aantal doktoren is wier passie voor kunst en cultuur uiting heeft gevonden in de behandeling van de medische klachten van kunstenaars. Een lichtend voorbeeld hiervan is de orthopeed A.B.M. Rietveld die in 1993 het Medisch Centrum voor Dansers en Musici (MDCM) in den Haag oprichtte. Ondanks het feit dat de oprichter ervan uitvoerend musicus is, heeft het centrum zich naam verworven voor de diagnose en behandeling van de klachten van zowel musici als dansers (beroeps en amateur).

\section{Medische problematiek}

De medische problematiek van dansers omvat een spectrum van aandoeningen, van de lage rug tot de grote teen. ${ }^{1}$ Naast routine orthopedische zaken, zoals meniscus-pathologie en verzwikte enkels, komt een aantal meer gespecialiseerde aandoeningen om de hoek kijken zoals stressfractuur van de wervelboog, pirformis syndroom, 'kissing spines', sartorius enthesopathie, dansers hiel, dansers tendinitis, juveniele hallux rigidus en 'sesamoiditis'.

In tegenstelling tot de dansers kampen musici vooral met problemen in de bovenste extremiteiten. ${ }^{2}$ Er is vaak sprake van een mengvorm waarbij diverse spierklachten en een slechte houding op de voorgrond staan. Specifieke tendinopathieën en zenuwinklemmingen komen vaak voor. Voor beide beroepsgroepen is een zeer gerichte anamnese noodzakelijk. De factoren die bijdragen aan het veroorzaken van overbelasting kunnen onder andere zijn: verandering van docent, techniek, dansvloer, instrument, repertoire en het aantal uren dat gedanst of gespeeld wordt. Hierover wordt grondig doorgevraagd bij het afnemen van de anamnese. Een hulpvraag bij nerve-entrapment is: "In welke stand is uw elleboog/pols tijdens het slapen?"! Met deze informatie kan soms de juiste rustspalk al gekozen worden.

Lichamelijk onderzoek eist een enorme kennis, niet alleen van het bewegingsapparaat maar ook van de danshoudingen (eerste positie, relevé, demi-plié, arabesque, enz.) en de instrumenten. Een gebied van slechts een paar vierkante centimeter ter hoogte van de pols kan al een waaier van diagnosen omvatten (bijvoorbeeld roeierspols, De Quervain's tendinitis, ganglion, extensor peesirritatie bij carpal boss, dorsale impingement syndroom). De musici worden uitgenodigd hun instrument mee te nemen naar het spreekuur ( $\mathrm{er}$ is een piano op de polikliniek beschikbaar) en hun speeltechniek en houding worden onderzocht. Soms is het slechts mogelijk de juiste diagnose te stellen tijdens het spelen, zoals bij focale dystonie.

Het is vaak tijdrovend werk en extra aanvullend onderzoek is soms zeer zinvol. Naast routine foto's zijn er bijzondere opnames noodzakelijk, bijvoorbeeld $3 / 4$ foto's van de lumbale wervelkolom om stressfractuur te herkennen en een lateraal foto van een enkel in relevé om os trigonum vast te stellen. Echografie helpt in de differentiatie tussen ganglion en peesschede- 
verdikking alsmede bij het vinden van de oorzaken van anterior heuppijn. Afhankelijk van de situatie worden andere technieken toegepast: skeletscintigrafie, CT, MRI (beide +/- arthrogram). Electromyografie kan van nut zijn bij mensen met intrapment neuropathieën.

Aangezien zowel bij dansers als bij musici maar zelden een operatie nodig is, wordt meestal gekozen voor een conservatieve behandeling, en wordt een belangrijk deel van het consult ingenomen door het 'therapeutische gesprek'; dit betreft uitleg en adviezen over de wijze waarop omgegaan kan worden met de klachten - het liefst zonder de dans/muziek (volledig) te hoeven staken - om tot genezing en secundaire preventie te geraken. Door de hoge en bijzondere eisen die het dansen en het musiceren aan deze beroepsgroep stellen, is enerzijds een minimale blessure al snel een maximale belemmering voor de beoefenaar en worden anderzijds, juist door die hoge eisen, de belemmeringen door de patiënt al in een ongebruikelijk vroeg stadium opgemerkt. Daarnaast is het een feit dat ook een niet aan de uitvoerende kunst gerelateerd trauma zeer nadelig kan zijn. Vallen van de fiets komt vaak voor in Nederland, helaas ook bij musici; een elders gemiste scaphoid fractuur bij een violiste en een avulsiefractuur van een falanx bij een gitarist hebben bij ons hun juiste aard gevonden.

\section{Behandeling}

De behandeling die wij hanteren is zeer gericht op de specifieke diagnose en, waar mogelijk, eventueel aangepast met de bedoeling om de danskunst/muziek nog te kunnen blijven beoefenen. Pijnbestrijders en ontstekingsremmers worden nauwelijks gebruikt omdat deze belangrijke waarschuwingssignalen kunnen verbloemen. Aandacht wordt wel besteed aan veel uitleg, houdingsadvies en rekoefeningen. Lokale injecties worden zorgvuldig toegepast en, indien nodig, wordt een operatie verricht (vaak in dagopname).

Alhoewel een zekere maat van lenigheid gunstig kan zijn bij dansers en musici, kan hypermobiliteit ook gepaard gaan met klachten, denk aan hyperpronatie bij dansers en overrekbare vingers bij musici. Onze deskundigheid op dit gebied heeft geleid tot het geven van adviezen aan andere categorieën patiënten (variërend van dierenarts tot beeldhouwster).

Tot nu toe heb ik over de somatische klachten geschreven terwijl wij allemaal op de hoogte zijn van de psychische stress die een uitvoerende baan met zich mee kan brengen. Regelmatig vinden dan ook verwijzingen naar (neuro-) psychologen en psychiaters plaats.

\section{Preventie}

In de laatste jaren hebben ook de preventieve aspecten meer aandacht gekregen. Een dans-orthopedische keuring voorafgaand aan een beroepsdansopleiding wordt door sommige dansscholen geëist. Instructie wordt ook gegeven aan conservatoria en er wordt veel gebruik gemaakt van Mensendieck oefentherapeuten en fysiotherapeuten. Het onderwerp 'dans- en muziekletsels' is een apart hoofdstuk in een Nederlandse orthopedische 'bijbel' en Rietveld geeft jaarlijks een klinische demonstratie aan studenten geneeskunde in Leiden. Medische studenten met affiniteit voor dans en/of muziek lopen met regelmaat stages in het MCDM en zijn hier hartelijk welkom.

\section{Literatuur}

1. Rietveld ABM. Dans- en muziekletsels. In Orthopedie: hoofdstuk 9. Red.: Verhaar JAN en Mourik JV. Houten: Bohn Stafleu Van Loghum; 2008. [Rietveld ABM. Dance and music injuries. In: Orthopaedics. Verhaar JAN en Mourik JV eds. Houten: Bohn Stafleu Van Loghum; 2008]. 
2. Macfarlane JD, Rietveld ABM. Reumatoloog houdt vinger aan de pols in muziekkliniek. Ned Tijd Reum 2009:2;23-25. [Macfarlane JD, Rietveld ABM. Rheumatologist keeps his finger on the pulse in music clinic. Netherlands Journal of Rheumatology 2009:2;23-25].

\section{De auteur:}

Dr. J.D. Macfarlane is reumatoloog en musicus, Medisch Centrum voor Dansers en Musici, MC Haaglanden, Den Haag.
Correspondentieadres:

Dr. J.D. Macfarlane, MCDM, postbus 432, 2501 CK Den

Haag. E-mail: jmacfarlane@ziggo.nl

Belangenconflict: geen gemeld

Financiële ondersteuning: geen gemeld 